\title{
Illegal Oil Bunkering, Violence and Criminal Offences in Nigeria's Territorial Waters and the Niger Delta Environs: Proposing Extension of Informed Policymaking
}

\author{
Richard INGWE \\ Institute of Public Policy and Administration (IPPA), University of Calabar, P.M.B. 1115, \\ Calabar, Nigeria \\ ingwe.richard@gmail.com, cradle.africa@gmail.com.
}

While it illegal oil bunkering has gone on around the Niger Delta for about 30 years, it escalated more recently (2012 to present) thereby poses serious implications on many facets of in Nigeria economy, society, and environment. Government's plan to eliminate it or drastically curb the crime has been hampered by inadequate knowledge of the scale of its occurrence in terms of the patterns expressed by its varying intensities or magnitude of its aspects over space, time, and structure. To achieve the objective of highlighting the recent escalation of illegal oil bunkering in the Niger Delta, this article examined issues helpful issues. It briefly reflected on recent studies of the phenomenal crime, its attendant geopolitical and geo-economic consequences on multinational economies and societies: Nigeria, UK, nations located close to the foregoing: European countries -on the one hand; Nigeria's neighbors; Gulf of Guinea region- on the other. Other aspects that are briefly examined are: contextual explanation of Nigeria's political economy, society, and related histories. Considering and comparing the recent estimation of the history of illegal oil bunkering of over 30 years with a recent study of the phenomenon over less than ten years (2002-2008), it is proposed that a study that extends the temporal scale of the analysis, preferably covering the entire life-span of the phenomenon is necessary. It is concluded that reckoning that the result of the shorter term spatial-temporal analyses study was robust, findings of the longer-term study promises to provide valuable information for strengthening public policy/programs for reducing oil theft in the region. Some aspects of the proposed study are outlined.

Keywords: Spatio-Temporal Analyses, Oil Theft, Evidence-Based Policy, Niger Delta

$\mathbf{1}_{\mathrm{s}}^{\mathrm{s}}$ Introduction

Some challenges have been gnawing at the heart of Nigeria's nationhood warrant concerted action by academic researchers to strengthen evidence-based policymaking and administration. An African multinational counter-insurgency was most recently launched to respond to one of the challenges Nigeria has been facing. This pertains to the new terrorism, describing the mindless insurgency waged by the Islamic, Boko Haram, in northern Nigeria since 2009 to the present (2015) as has cost the country many thousands of human lives, displaced millions internally and internationally. Another debilitating challenge (illegal oil bunkering) in Nigeria's Niger Delta is yet to attract such serious attention. Nigeria's government functionaries e.g. the coordinating minister of the economy, Okonjo-Iweala had feared that having reportedly evolved for over 30 years and counting [7] "Oil theft:" could make Nigeria's government to "lose \$12bn in 2013 ..." [25]. Both violent challenges have been enormously costly to the Nigerian State as well as Nigerians [19] [21] [18]. While a comprehensive record of the history including costing of illegal oil bunkering is yet to be undertaken it has been attracting academic research attention. By analyzing offences perpetrated by ocean-going vessels in Nigeria's territorial waters in the late 2000 s, the present author led co-workers to inform on the activities of people most likely involved in illegal oil-bunkering in the area within the Niger Delta [10].

The cost of illegal oil bunkering to Nigeria's government in terms of forfeited revenue 
(sizes) has more recently been variously estimated at over a quarter of its annual national budget. The losses arising from illegal oil bunkering to Nigeria's government has been estimated at $£ 7 \mathrm{bn}$ a year, the crime causes other stakeholders e.g. the United Kingdom, United States of America, and their allies to incur losses [19] [7] [21]. Moreover, it was reported in 2014 that Nigeria's President "Jonathan plans to Spend \$1Billion..." in a policy taking aims at curbing oil theft in the Niger Delta [11].

\subsection{Problematizing President Jonathan's desire to tackle illegal oil bunkering: inadequate knowledge of the crime perpetration}

President Jonathan's plan to tackle illegal oil bunkering requires the formulation of a policy and the latter's implementation in terms of a program (and projects) aiming towards ensuring that various facets related to the challenge are properly understood before meaningful management -including planning can be undertaken. For example, some of the various aspects or issues include: security of oil infrastructure, resolving community issues, managing other programs designed to empower the youth. Moreover, the program would establish structures and processes covering apprehension, prosecution of oil thieves whom President (Jonathan) described as terrorists [11] [7]. The foregoing plan by President Jonathan indicates some of the information and knowledge needs required for strengthening the special-purpose, and evidence-based policymaking, planning, program/projectsdesign and implementation management. More importantly, we show elsewhere in this article (see literature review) how aspects of our previous research indicates the way various dimensions (spatial, temporal, and structural) of the phenomenon could be better understood through analysis of patterns that could be built from data gathered of them.

Some consequences of the current scale of illegal oil bunkering include possibilities that should adequate precautionary measures not be taken/implemented to curb its escalation beyond current levels, powerful socioeconomic and political groups capable of posing enormous resistance to Nigeria's federal government and perpetuation of the current enormous economic sabotage that threatens government are possible outcomes. I have hinted already that most publics e.g. including academic researchers, policy/decision makers, functionaries of government, among others, poorly understand the current scale of illegal oil bunkering and the multi-dimensional challenges it poses to the Nigerian state, its economy, its polity, its society, its environment, among other facets of the country.

\subsection{Objectives and Organization}

The overall objective of this article is to draw attention to the recent escalation of illegal oil bunkering in the Niger Delta. Specifically, I reflect on previous studies of the phenomenal crime and the attendant consequences on multinational economies and societies (Nigeria, UK, and other nations neighboring the UK i.e. European countries -on the one hand; and located closely to Nigeria within the Gulf of Guinea region- on the other. I also provide contextual explanation of Nigeria's political economy, society, and related histories. Then, I consider and compare the recent estimation of the history of illegal oil bunkering of over 30 years with previous study of the phenomenon over less than ten years (2002 - 2008) and make a case for a study that extends the temporal scale of the analysis, preferably covering the entire life-span of the phenomenon. Finally, I conclude by summarizing the main points and clarify the direction for the proposed further study.

\subsection{Socio-political, economic and environmental contexts}

A brief history of Nigeria is important for understanding the country's rather complicated society, economy, and environment, among other characteristics. As a modern nation-state, Nigeria represents the product of British colonial contrivance of 
foreign territories that were acquired in line with its quest for socio-economic expansionism since the $17^{\text {th }}$ century and earlier. Prior to the amalgamation of the Southern Protectorate of Nigeria to its Northern counterpart by Lord Frederick Lugard in 1914, the two regions also created by British colonialists originally existed as independent nationalities currently identified by their distinctive ethnic/cultural characteristics e.g. language -different from English, among other traits, as numbering about 250 to 300 . Exploitation and manifold injustices perpetrated by British colonialists against natives (Nigerians) provoked agitation for political independence by nationalists culminating in the granting of independence on $1^{\text {st }}$ October 1960. Prior to that, series of exploration for petroleum oil by various companies led to the discovery of commercially viable deposits of the "Black Gold" in Oloibiri, a community currently located in Bayelsa State, by the Royal Dutch oil firm -Shell d Archy- in the late 1950s [3].

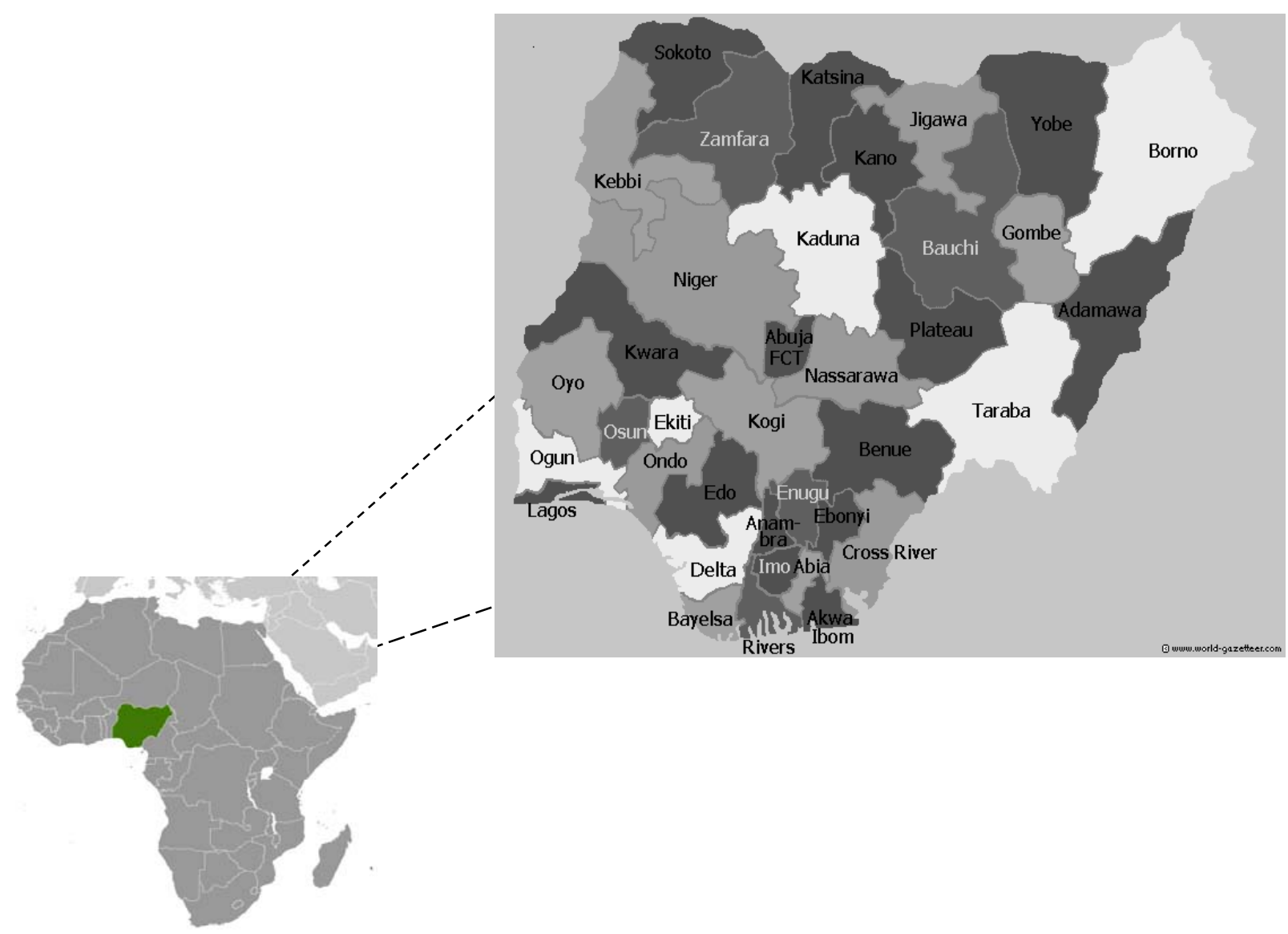

Fig. 1. Nigeria showing Nigeria's States projected from Africa

Sources: Africa with Nigeria inset (604 x 672 - $22.9 k$-gif) retrieved 25 January 2013 from [27]; Nigeria with States and FCT $(812 \times 714$ - $37 k-p n g)$ retrieved 25 January 2013 extracted from [28] [8].

\subsection{Political Independence without implemented at the time and only agreed to Economic Power \\ the later date in 1960.}

This oil find coincided with the period of intensification of agitation for independence when political leaders of what was the Northern Nigerian Protectorate declined the scheduling of political independence to be

\subsection{Revenue Generation and Spending}

Fiscal federalism of the pre-independence period involved administration of the nation through three regions (South-East, SouthWest, and Northern), later expanded through 
the creation of an additional one, Mid-West from the South-West. Economic management -including planning and implementationinvolved generating and spending of revenue from agricultural activities for investment in local-regional development internally i.e. within each of the sub-national regions. This economic management model is being hailed as Nigeria's good old days because of the way it promoted speedy improvement in subnational regional socio-economic fortunes. Some examples include development of universities within most of the regions, among other signals of improving fortunes. This scenario changed shortly after independence when distrust by the elite representing ethnic nationalities, perceptions and charges of marginalization and injustice led to quarrels and culminated in the bitter 30-month civil war waged by Biafra (Igbo cultural group of south-eastern Nigeria) with Nigeria's Federal Republic, created in 1963 between 1967 and 1970. One of the measures that were introduced to curb increasing ethnicity as well as the clinging to the major regions was the creation of more (12) states by General Yakubu Gowon's dictatorship in 1967. More states and local government areas (LGAs) have been created afterwards to make the current administrative structure whereby Nigeria comprises 36 states, 774 LGAs, with their communities. In the 2000s up to the present, discourses on the creation of the Nigerian nation out of the rather complicated socio-political-economic structure implicates the habitual resort of the elite to ethnic cleavages [4].

\subsection{Justification}

Academic research on illegal oil bunkering in Nigeria's Niger Delta is warranted for many reasons but only few deserve mention immediately. Apart from the need for evidence to inform convention maintenance of security, law, as foundations for social order, the need for information to strengthen policy on manifold aspects of Nigeria's society, economic growth, is urgent and imperative.

\section{Theoretical Framework}

Owing to the way its application leads to improvement of decision making, the normative theory of rational choice (RCT), itself frequently employed as a theory in most decision making tasks is adopted in this study. It is founded on the habit of rationality and has been well documented in the literature. Therefore, rather than repeating its elaboration here, it suffices to briefly state its major points here while referring readers to its fuller presentation elsewhere [9]. The latter action aims to allow create space and resources - that I prefer to devote towards accomplishing other more urgent tasks relevant to this study. The central idea proposed by proponents of rationalism (and rational choice theory) for clarifying human behavior, which according to geographer, Trevor J. Barnes [5] [2] was transferred to the social sciences from the physical sciences is that all human actions are founded on rationality. The latter term refers to the use of perfect knowledge by Man (used here to refer to both male and female gender), considered as a rational being perpetually seeking to achieve inexhaustible goals amid scarce means/resources, for deciding on the best courses of action that satisfies the decision maker's most important need(s). Three steps usually taken by the rational Man to achieve his goals include: consideration of all available alternative courses of action; exhaustive identification and evaluation of possible consequences that could arise from applying each of the alternatives; and, selection and application of the option that best meets the actor (decision maker)'s needs within the resource-constrained setting [23].

\subsection{Literature Review}

Most analyses of relationships between natural resources endowment -viewed generically- in many developing countries' sovereign-states and the extent of stability within various socio-political and economic systems point towards two broad areas of concentrations of academic geographers. First, are contests for resources of rather fierce forms leading to violence and wars. 
Examples are resource wars that are, by and large, waged by conflicting groups or classes within Developing Countries (DCs). Contributions along this line of academic research area involving analyses of violence in many DCs (Angola, Sierra Leone, etc.) have come from geographer, Phillipe Le Billon -either alone or in collaboration with colleagues [13] [14] [15] [16] [17]. Economists including [1], among others, have also been involved in this scholarship line. Second, literature emphasizing resource wars and violence initiated by the global West (UK, USA, among other nations implicated in classical geopolitics, the expansion of socio-economic and political interests through military campaigns aimed towards conquest, acquisition of foreign territories. The latter investigations are yet to be more deeply reviewed. However, Lise Namikas' recent [20] account partly entitled "(B)attleground Africa" indicates the historical and huge victimization of Africa such that the immediate focus on contests for the multiple resource-rich (e.g. Uranium, etc.) Congo by multinational interests of countries experienced in deploying military geopolitics (colonial Belgium, defunct USSR, USA, China, United Nations, among others) sheds light on conflicts in the Congo in the 1960s might just be a starting point for understanding others whose detailed accounts are hidden in national intelligence reports of the geopolitically "dense" nations involved in similar crises. Namikas' [20] report indicates the intensity of similar multinational contests for resources elsewhere in Africa (e.g. Central African Republic). As recently reviewed, Germany, Great Britain, The Netherlands, USA, have been leading such campaigns (see [7]; [5].

Third, scholars have highlighted issues in the nexus of governance but especially exposing flaws in the nature of public economic management characteristics of nation-states namely petro-capitalism in oil-producing developing countries (DCs): e.g. Angola, Nigeria, among others. Geographer, Michael Watts has contributed to this strand of academic geography [26] in [5], etc. I note that this brand of scholarship could be distinguished by its focus on petroleum (although its treatment of natural gas i.e. separated from oil remains, by and large, scanty and less visible), and either the mixing of all manner of subjects or topics related to petroleum in the discourse and/or the feeling that a separate discussion of violence as a distinctive area of governance failure is unnecessary or both.

\subsection{The Empirical Literature}

The literature reveals that despite costing Nigeria enormously, oil theft presents many intrigues. For example, Nigeria's government ordered the release of 148 vessels arrested by armed forces as a result of their involvement in oil theft [24]. A necessary question to ask ought to be: why would government order the release of vessels engaged in criminal activities? As if that is not enough, it was reported that four officers of Nigeria's Navy sued the Chief of Navy and Nigeria's Federal Government, over their premature retirement as a result of their involvement in the vessels apprehended for carrying out illegal oil bunkering a.k.a. oil theft [12].

The method facilitated understanding of the magnitude (intensity) of the problem of offending ocean-going vessels within the Nigerian territorial waters. The explanation offered by the concept/method clarified issues regarding public programmes planned for remedying areas presenting high intensity of offences. It was suggested that the patterns that were found could be superposed or matched with other factors (e.g. policies, programmes, etc.) and the way they were differently applied over the space i.e. Navy operational areas.

The method of spatio-temporal analysis -a contraction of separate studies of phenomena along the dimensions of space and time - was applied to study offending oceangoing vessels in southern Nigeria -especially the Niger Delta and many of the southern coastal seaports commonly traversed by the oceangoing vessels). Data covering eight years (2002 - 2008) were obtained from secondary sources, namely: the Nigerian 
Navy, responsible for apprehending such offending vessels. Some of the aspects emphasized in the analysis include: Spatial Distribution of Offending Vessels; Spatial Variation of Specific Illegalities; Illegal Bunkering by Area -corresponding to Navy operational areas: Port Harcourt, Warri, Igbokodah/Ondo, Calabar, and Apapa.

3 Temporal Distribution of the Offending Vessels, another major dimension of the analysis undertaken examined this dimension under the following aspects: Type of Illegalities Committed (illegal bunkering and crude oil theft dominated with 76.5 and $7.4 \%$, respectively while others violated rules relating to limits of movement in the context of violent conflicts between feuding communities in the Niger Delta region). Theft of Crude Oil was concentrated in Apapa area (90.9\%) and Port Harcourt (9.1\%); Militancy by Area was concentrated in Port Harcourt $(100 \%)$; Stealing of Condensate was concentrated in Warri $(100 \%)$. Suspicion of stealing condensate -by area- revealed concentration in Apapa (50\%) and Port Harcourt (50\%) and General Offences by Naval Operational Areas.

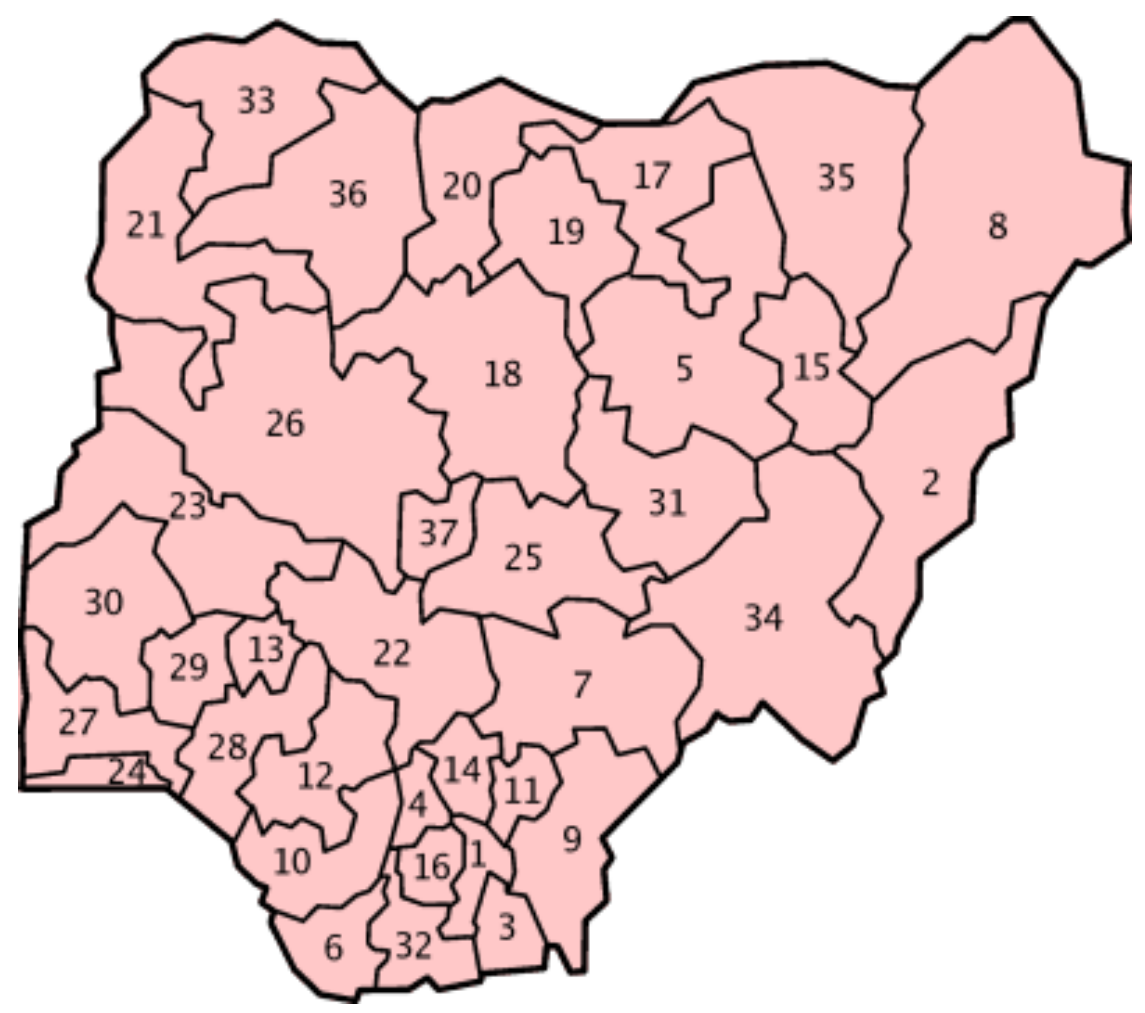

Fig. 2. Nigeria's states located within its territorial waters/littoral area [29]

Some of Nigeria's states bounding its territorial waters (littoral area), many within the Niger Delta also bound the Atlantic Ocean: Akwa Ibom (3); Bayela (6); Cross River (9); Rivers (32); Imo (1); Delta (10); Edo (12); Ondo (28). While some e.g. Lagos (24), Ogun (27) are part of the Niger Delta, oil theft operations might occur within their territories.
3.1 Value added by previous spatio-temporal analysis

The method facilitated understanding of the magnitude (intensity) of the problem of offending ocean-going vessels within the Nigerian territorial waters. The explanation offered by the concept/method clarified issues regarding public programmes planned for remedying areas presenting high intensity of offences. It was suggested that the patterns that were found could be superposed or matched with other factors (e.g. policies, 
programmes, etc.) and the way they were differently applied over the space i.e., Navy operational areas.

The findings -mentioned above- revealed that Nigeria's national territorial waters around the south eastern part of the country that falls under the operation of NNS Pathfinder (Port Harcourt) was pervaded by a high intensity of vessels perpetrating illegal bunkering. Several vessels that we suspected to be involved in illegal bunkering were most common in South Western (i.e. around Warri urban region described in Navy circles as NNS Delta province. Owners of the vessels that were suspected to be involved in illegal bunkering in the NNS Delta area instituted legal proceedings in the Courts aiming to recover their properties. The latter was contrasting to the failure undertake legal proceedings to recover their properties by owners (and/or operators) of most vessels that were arrested for perpetrating (or suspected of trying to do so) in the South Eastern (Port Harcourt) area. It was easy to highlight one of the policy implications of the study in terms of intensifying the monitoring of offences perpetrated by oceangoing vessels around South-eastern Nigeria which appeared to require the strengthening of its legal processing institutions to make for a hitch-free reign of the rule of law in the region.

\section{Methods and Data}

The hypothetic-deductive scientific methodology proposed by human geographer, David Harvey [6] as appropriate for scientific explanations lends itself to a study of this nature. The methodology is compatible with both methods (spatial and temporal analyses applied in previous studies related to this as well to all used in scientific programs/projects and to be undertaken arising from this proposal.

\subsection{Description ${ }^{2}$}

I use the method of description for implementing this study. Researchers have reported that description has served as a veritable and suitable method for investigating issues of the kind proposed in this article that concern relatively unpopular matters. Description and desk research emphasize the introduction of issues that are relatively new and poorly understood ${ }^{3}$ but deserving the attention of the academy (researchers) and policymakers that could be accomplished with minimal demands for sophisticated quantitative analyses except for rudimentary statistical (averaging tools). Description has served creditably well for purposes of the kind undertaken here and also proposed in this study [22].

\subsection{Objectives of the Proposed Study}

The overall objectives of this proposed research project is to contribute more comprehensive knowledge on various aspects of the study earlier started -including violence associated with illegal oil bunkering in the Niger Delta.

There are many reasons to revisit the study of illegal oil bunkering or oil theft of the late 2000 s. Following recent information that illegal oil bunkering has a history of over 30 years and considering that the related study of the criminal phenomenon has not only escalated but continued since its study in the late 2000s, the need to add relevant information concerning various aspects of the crime for expanding understanding of issues involved is urgent and imperative in the light of its escalation and persistence. Put differently, policymaking should be interested in answers to questions concerning: the magnitude, geographic extent, structural aspects among other points of the bits of phenomena as defined earlier [10].

\subsection{Data Availability/Supply and Spatio- Temporal Scaling of the Proposed Investigation}

Owing to the constraints and challenges related to data gathering and reliance on data provided by the Armed Forces (especially the Nigerian Navy) to supply secondary data, much of the spatial and temporal dimensions or scales of the proposed study would depend 
on the supply-side determinants or factors of the research.

\subsection{Other Specific Needs for Information/ Knowledge}

I'm interested in clarifying some aspects of the crime and/or activity: (i) the spatial and temporal patterns expressed in the perpetration of the crime/activity in various communities of the Niger Delta; (ii) the legitimation of the practice within communities, localities/areas where it has occurred most intensively; (iii) Recent history of various inter-relationships between the formal sector of government including its ministries, department and agencies (MDAs), security agencies (armed forces, intelligence gatherers or state security), legislature and judiciary etc., have worked towards curbing the crime.

New scholarship highlights the challenges in the arena of Nigeria's relations with other nations (United Kingdom, other European nations and those in the Gulf of Guinea) arising from oil theft and piracy stretching from the Niger Delta to the Gulf of Guinea [7]. These are issues that related research could undertake to cover.

\section{Conclusion}

The overall objective of this article was to highlight the recent escalation of illegal oil bunkering in the Niger Delta. In achieving that objective I specifically reflected on previous studies of the phenomenal crime and the attendant consequences it has posed to multinational economies and societies especially Nigeria's as well as those of the UK, and other nations neighboring the UK i.e. European countries - on the one hand; and those located closely to Nigeria within the Gulf of Guinea region- on the other. I also provided contextual explanation of Nigeria's political economy, society, and related histories. Then, I considered and compared the recent estimation of the history of illegal oil bunkering of over 30 years with one available study of the phenomenon over less than ten years (2002-2008) before making a case for a study that extends the temporal scale of the analysis, preferably covering the entire life-span of the phenomenon. Conclusively, I reckon that -as demonstrated by the robust results obtained from the spatio-temporal analyses of offenses perpetrated by ocean-going vessels between 2002-2008- the proposed study shall provide valuable information for strengthening public policy/programs for reducing oil theft in the region.

As proposed, the study is limited in terms of fulfilling all the needs for evidence (information, knowledge, among other facts) required for policymaking and implementation to drastically curb and/or eliminate illegal oil bunkering in the region to be investigated. Other dimensions that warrant separate studies are too many to exhaustively list here. However, there is need to mention the governance issues pertaining to national oil revenue generation, infrastructural development investment in various parts of Nigeria as this relates to the Niger Delta, among other components of the country. Also not excluded from the study are related factors such as many histories of fiscal regimes, the political economies of Commissions of enquiries set up to examine and recommend ways of tackling multifaceted development challenges of the Niger Delta since the era of British colonialism and so forth. The policy implications of this study includes the need for government to appreciate, and by extension invest, in information and knowledge production specially designed for promoting evidence-based policymaking on oil theft in the Niger Delta and the environs.

\section{Notes:}

1. Petroleum oil is only an example of the diverse categories of natural resources. This is the view in the literature that many types of natural resources as variably distributed around the world in different countries. Some examples of resources covered by the literature cited in connection with this study include: oil, diamond, among others. 
2. Of course, the proposed research could opt to apply other methods different from description. I would like to employ aetiology for implementing some of the proposed study.

3. There is a cogent reason for viewing oil theft as poorly understood and relatively new phenomenon. As argued above, previous spatio-temporal analysis of illegal oil bunkering and/or oil theft [10] was limited in terms of the the scales i.e. number of tears covered viz: seven of over 30 years that the crime has lasted in Nigeria.

\section{References}

[1] I. Bannon, P. Collier. (eds.). 2003. "Natural resources and violent conflicts: options and actions", Washington, D.C.: World Bank.

[2] TJ. Barnes. 1996. "Logics of dislocation: models, metaphors, and meanings of economic space", New York: Guilford Press.

[3] A. Dosunmu, 2013, "Oil and gas industry overview" (Unpublished lecture notes, Emerald Energy Institute, EEI, University of Port Harcourt). November.

[4] IA. Eteng. 2008. "Ethnicity, Ethno-Class Relations and Crisis of Nigeria's

Enduring 'National Question' and Political Instability", In: D. Oni, S. Gupta, T Omoniyi, E Adegbija, \& S Awoniusi (eds.) Nigeria and Globalisation: Discourses on Identity Politics and Social Conflict. Lagos: Centre for Art, Black Civilisation and Culture: 37-81.

[5] D. Gregory, R. Johnson, G. Pratt, M. Watts, \& S. Whatmore (Eds.). 2009. The Dictionary of Human Geography. Chicester: Wiley-Blackwell.

[6] D. Harvey. 1969. Explanation in Geography. London: Arnold.

[7] R. Ingwe, JK. Ukwayi, EU Utam. 2014. Nigeria's relations with the United Kingdom and its Allies in the Light of Oil theft in the Niger Delta and Piracy in Gulf of Guinea: A geopolitical perspective, IUP Journal of International Relations. October: 24-39.
[8] R. Ingwe. 2014. Cyber-spatial academic networking for energy (oil, natural gas, electricity) development in Nigeria, Informatica Economica, 18 (3), 2014: 6676.

doi.10.12948/issn.14531305/18.3.2014.0 6.

[9] R. Ingwe, E. Odu, MO. Ojong, \& I Angiating. 2010. Need for Rationalism: Proposing Geo-Information Solutions for Surmounting Challenges Hampering Administrative Management of Voters Registration in Northern Cross Rivers State, Nigeria. International Journal of Business and Behavioural Sciences, Vol. 2, No. 3, March: 29-41.

[10] R. Ingwe, JA Adams, SPI Agi, JE Otu, \& JK Ukwayi. 2009. Perpetration of offences by ocean-going vessels in Nigeria's territorial waters, ICFAI University Journal of Governance and Public Policy, vol. 4, No. 1 (Hyderabad), March, 2009: 35-48.

[11] IReports (Irng.com). 2014. "Jonathan To Spend \$1Billion To Curb Oil Theft In Niger Delta”. Retrieved 21 July 2014 from: http://ireportsng.com/2014/03/23/jonathan-to-spend1 billion-to-curb-oil-theft-in-niger-delta/. 23 March 2014.

[12] K. Ketefe./ The Punch (Lagos). 2008. "Illegal bunkering: Four naval officers sue Adekeye, FG (Federal Government)", 25 March, 2008: 7.

[13] P. Le Billon. 2010. "Oil and armed conflicts in Africa" African Geographical Review. 29(1): 63-90.

[14] P. Le Billon, A. Vines, A. Malaquias. 2008. "Angola's petro-militararism and external relations » Politique Africaine, 110 : 102-121.

[15] P. Le Billon. (ed.) 2005a. The Geopolitics of "Resource Wars". Resource Dependence, Governance and Violence. London: Frank Cass.

[16] P. Le Billon. 2005b. Corruption, reconstruction and oil governance in Iraq, Third World Quarterly, 26 (4): 679-698.

[17] P. Le Billon. 2005c. Aid in the midst of plenty: oil wealth, misery and advocacy 
in Angola, Disasters, 29 (1): 1-25.

[18] A. Mähler. 2010. Nigeria: A Prime Example of the Resource Curse? Revisiting the Oil-Violence Link in the Niger Delta. GIGA Research Programme (Violence and Security), No. 120. January 2010. Retrieved 16 Sept. 2014 from: hamburg.de/workingpapers/.

[19] The Guardian. 2013. "£1bn a month: the spiralling cost of oil theft in Nigeria". Retrieved 22 July 2014 from: http://www.theguardian.com/globaldevelopment/2013/oct/06/oil-theft-costsnigeria.

[20] L. Namikas. 2013. Battleground Africa: Cold war in the Congo, 1960-65. Washington, D.C.: Woodrow Wilson Centre Press; Stanford, CA: Standford University Press.

[21] Nigerian Watch. 2014. "UK Chamber of Shipping says Nigeria loses over $£ 7 b n$ a year to oil theft in Niger Delta" - See more

at:http://www.nigerianwatch.com/news/4

790-uk-chamber-of-shipping-says-

nigeria-loses-over-p7bn-a-year-to-oil-

theft-in-niger-

delta\#sthash.I2yBfpCK.dpuf. Accessed

21 July 2014. Published/Uploaded 12 July 2014.
[22] MB Ogunniyi. 1992. Understanding Research in the Social Sciences. Ibadan: University Press PLC. 132.

[23] GED Omuta, \& AG Onokerhoraye. 1986. Regional Development and Planning,

Benin-City: University of Benin (Department of Geography and Regional Planning), 255.

[24] M. Onuorah. 2008. "Government orders release of 148 vessels linked with oil theft", The Guardian (Lagos), 14 March, 2008: 3 .

[25] "Oil theft: FG may lose \$12bn in 2013 - Okonjo-Iweala ...”. Retrieved 21 July 2014 from: http://naijabizcom.com/2013/11/oil-theftfg-may-lose-12bn-in-2013-okonjoiweala/.

[26] M. Watts, 2009. "Petro-capitalism" in: D. Gregory, R. Johnson, G. Pratt, M. Watts, \& S. Whatmore (Eds.). 2009. The Dictionary of Human Geography. Chicester: Wiley-Blackwell: 527-528.

[27][http://www.worldofcultures.org/1024/af rica/AfricaMaps/nigeria.gif]

[28][http://mapsof.net/nigeriaciting www.world-geographics.com]

[29][http://mapsof.net/map/nigerian-statesby-population\#.UQe3v1fU_IX].

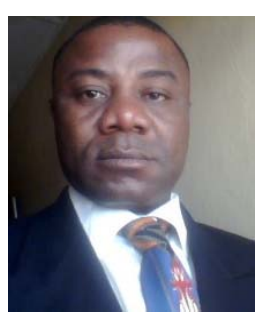

Richard INGWE applies inter-/trans-disciplinary methods of spatialregional development management -including (re)planning- for formulating solutions to sustainable development challenges. His eclectic professional and academic skills include natural resources management e.g. petroleum/energy e.g. electricity, forestry, geo-demography and population analysis for infrastructure development, among others. His recent development programme/projects and research interests concentrate on developing/managing plans aiming towards promoting downstream petroleum industrialization e.g. establishing and managing oil refining and petrochemical plants in subSaharan Africa including the region's largest economy, Nigeria. He is experienced in working as a consulting expert with (sub)-national governments, international governmental organizations (UN agencies) in the foregoing, among other development issues on which he has submitted and/or published technical reports, academic research articles, and/or speaks about to public audiences. 